
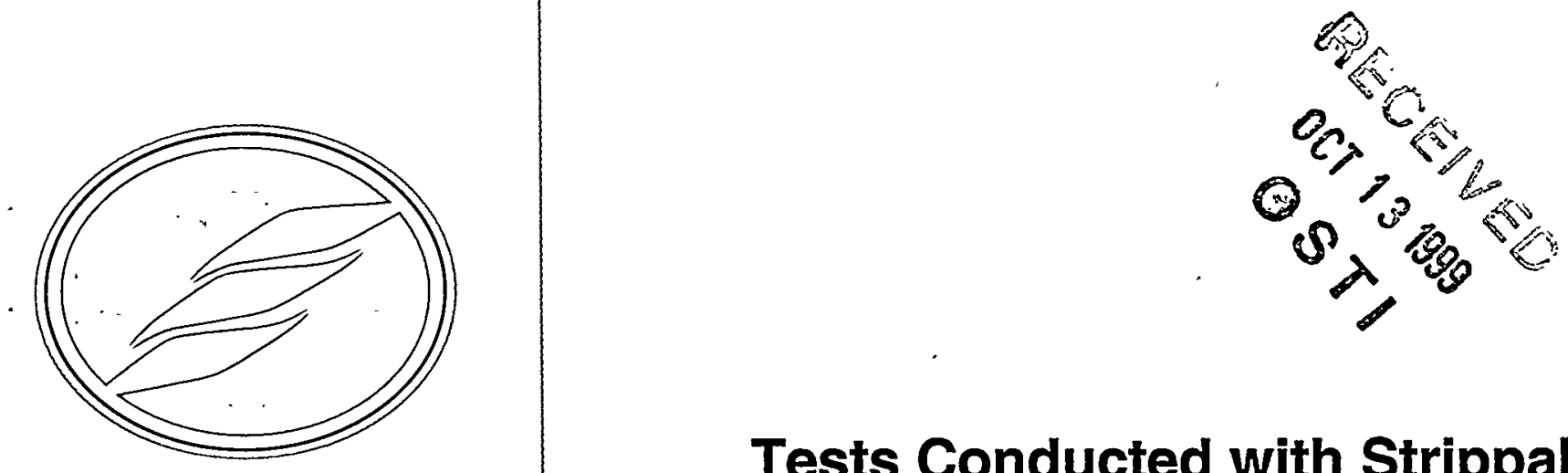

August 1999

\title{
Tests Conducted with Strippable Coatings
}

Kip E. Archibald Rick L. Demmer

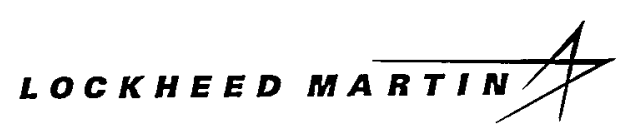


INEEL/EXT-99-00791

\section{Tests Conducted with Strippable Coatings}

Kip E. Archibald

Rick L. Demmer

Published August 1999

Idaho National Engineering and Environmental Laboratory High Level Waste Programs Lockheed Martin Idaho Technologies Company, Inc. Idaho Falls, Idaho 83415

Prepared for the

U.S. Department of Energy Assistant Secretary for Environmental Management Under DOE Idaho Operations Office Contract DE-AC07-94ID13223 


\section{DISCLAIMER}

This report was prepared as an account of work sponsored by an agency of the United States Government. Neither the United States Government nor any agency thereof, nor any of their employees, make any warranty, express or implied, or assumes any legal liability or responsibility for the accuracy, completeness, or usefulness of any information, apparatus, product, or process disclosed, or represents that its use would not infringe privately owned rights. Reference herein to any specific commercial product, process, or service by trade name, trademark, manufacturer, or otherwise does not necessarily constitute or imply its endorsement, recommendation, or favoring by the United States Government or any agency thereof. The views and opinions of authors expressed herein do not necessarily state or reflect those of the United States Government or any agency thereof. 


\section{DISCLAIMER}

Portions of this document may be illegible in electronic image products. Images are produced from the best available original document. 


\section{ABSTRACT}

This report details the testing and evaluation of several strippable coatings and their use in decontamination. Pentek 604, Bartlett (TLC), and ALARA 1146 were products examined for their overall effectiveness and ease of use. Conclusions were reached about the effective use of these coatings, and field test examples, with radioactive contamination are incorporated. 


\section{SUMMARY}

The Idaho National Engineering and Environmental Laboratory (INEEL) Radioactive Liquid Waste Reduction (RLWR) group conducted tests of several different strippable (removable) coatings, including Pentek 604, Bartlett (TLC), and ALARA 1146. The purpose of the tests was to determine how and where these coatings can be used to aid in the minimization of liquid waste generation. Quantitative data, such as effectiveness and costs, and qualitative data, such as issues like ease of application or removal, was determined. PENTEK 604 and Bartlett TLC were evaluated as superior products with several different uses. 


\section{ACKNOWLEGEMENTS}

The authors wish to express their appreciation and acknowledge the contributions of Victor Gonzales, Brenda Boyle, and Wayne Griffin in developing this report. 


\section{CONTENTS}

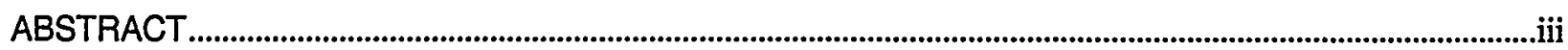

SUMMARY

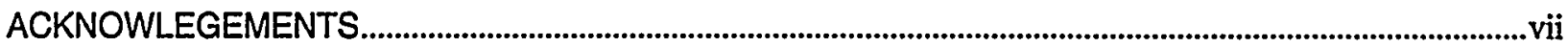

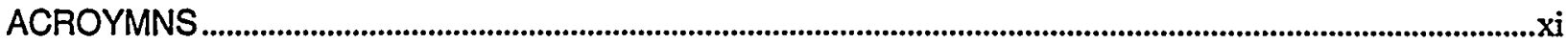

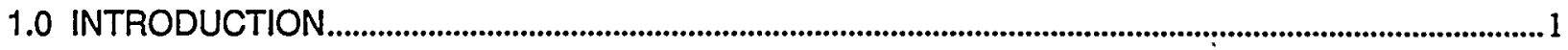

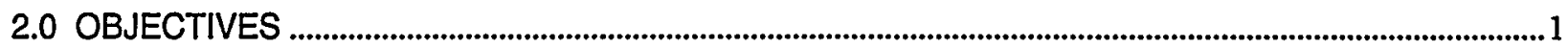

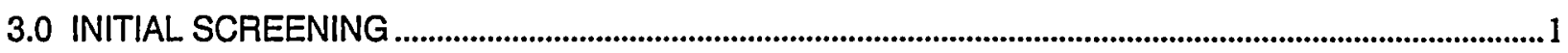

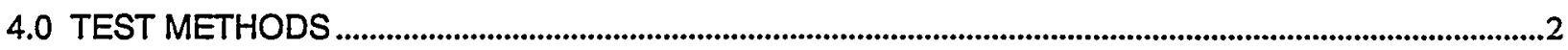

5.0 LABORATORY TESTS

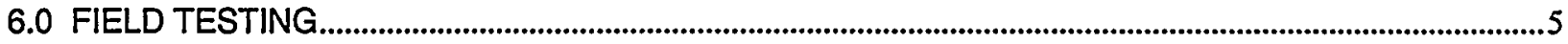

7.0 CONCLUSIONS

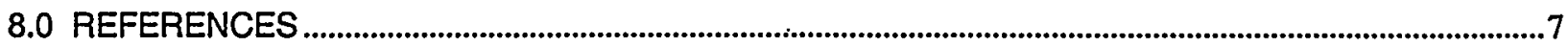

TABLES

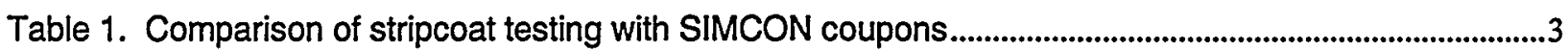

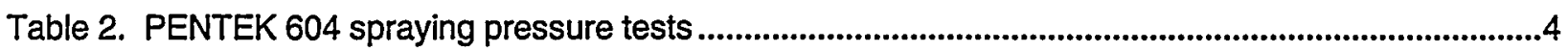

Table 3. PENTEK 604 SIMCON I decontamination spray test ......................................................................4

Table 4. Results of contamination lead brick cleaning ..........................................................................................5

Table 5. PENTEK 604 cleaning results for criticality barriers ..........................................................................6 
X

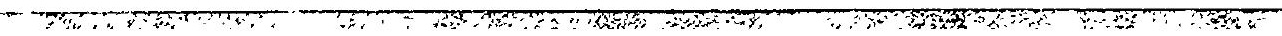




\title{
ACROYMNS
}

\author{
ALARA As Low As Reasonably Achievable \\ INEEL Idaho National Engineering and Environmental Laboratory \\ RLWR Radioactive Liquid Waste Reduction \\ SIMCON Simulated Contamination
}




\section{Tests Conducted with Strippable Coatings}

\subsection{INTRODUCTION}

The Idaho National Engineering and Environmental Laboratory (INEEL) Radioactive Liquid Waste Reduction (RLWR) group has conducted a testing and evaluation program on strippable coatings. The purpose of the program is to determine how and where these coatings can be used to aid in the minimization of liquid waste generation. In the past other types of strippable coatings were used to help control the spread of contamination in cells. However, these coatings were extremely labor intensive when it came time to remove the coating from the surfaces. One aspect of the testing presented here is the realative ease of removal. The testing of the strippable and protective coatings was performed over a period of months. Results of the 1996 to 1998 testing will be presented in this report. These coatings have become more important in daily operations because of the increased concern of secondary liquid waste generation at the INEEL.

Several different strippable and protective coatings were investigated by the RLWR group, including Pentek 604, Bartlett (TLC), and ALARA 1146. During the tests quantitative data was determined, such as effectiveness at reducing contamination levels and costs, and qualitative data on issues like ease of application or removal. PENTEK 604 and Bartlett TLC are seen as superior products with several different uses.

\subsection{OBJECTIVES}

The testing was performed to evaluate the best use of the coatings at the INEEL. In the past, some strippable coatings were used to control the spread of contamination. However, they have been very labor intensive when it came time to remove the coatings from the surfaces. The objective of these tests was to determine how effective the new coatings were at decontaminating, cleaning, and protecting items, and the relative ease with which they could be applied and removed.

\subsection{INITIAL SCREENING}

The following different types and brands of coatings were identified as applicable to various INEEL decontamination problems in the initial screening process:

Imperial Nuclear-ALARA-1146- This coating is a water-borne strippable coating intended for use in decontaminating smooth and semi-rough surfaces. It can be used on steel, concrete, aluminum, wood and painted surfaces. The coating is best used when it is sprayed onto the surface. After the coating has dried, it can be pulled from the substrate. The average drying time is 24 hours but varies depending on the relative humidity and temperature and can cover $27 \mathrm{sq} \mathrm{ft} / \mathrm{gal}$ at a thickness of 25 mils.

SensorCoat- This coating is currently being developed at Los Alamos National Laboratory. The coating is a water-based, non-toxic strippable coating. It can be sprayed, rolled or painted onto stainless steel surfaces. It is designed to change colors when applied to stainless steel surfaces contaminated with plutonium or uranium. 'SensorCoat can be pulled from the substrate after it has dried. In 1996, the coating was still in the development phase and had only been used on small-scale laboratory studies; it was not 
tested in this evaluation. The drying time will varies from 3-24 hours depending on humidity and film thickness.

Bartlett - Stripcoat TLC- This coating is a one-component, water-based, decontamination coating. It can be used to decontaminate floor/wall areas and equipment. Stripcoat TLC can be applied to metal, wood, concrete and painted surfaces. The coating can be applied with industrial spray equipment, paint rollers or brushes. After it has dried, it can easily be pulled off the surface. The average drying time for this coating is 4 hours and can cover 50 sq. $\mathrm{ft}$. /gal if applied at 25 mils.

WES Strip- This is a water-based strippable coating; it was not tested in this evaluation. The coating can be used on concrete, metal, wood, glass, and painted and non-painted surfaces. The coating can be applied with spray equipment, paint rollers or brushes. After the coating has dried it can be pulled off the surface. The average drying time is 4 to 6 hours.

Pentek - 604- This is a "self-stripping" coating that is normally applied with a brush or roller. It can be used on all types of material (i.e, plastic, glass, rubber) and all kinds of metal except carbon steel. PENTEK-604 is a water-based polymer, which is non-toxic, non-hazardous and non-flammable. One gallon covers approximately $120 \mathrm{ft}^{2}$. After the coating has been applied to the surface it will dry and fall off. The average drying time is between 3 to 4 hours; however, drying time will vary depending on the temperature and humidity of the area being treated. This coating is designed to remove loose, and some fixed, contamination.

\subsection{TEST METHODS}

After the initial investigation was completed, only the following coatings were tested because of ease of application and removal: ALARA 1146, TLC Stripcoat, and Pentek 604. Coatings that had to be applied by a licensed applicator or were still under development were not tested. Each of the selected coatings was applied to coupons using a brush to determine decontamination effectiveness.

Simulated contamination (SIMCON) coupons were used for these tests. These coupons are stainless steel disks about $1 / 4$ " in thickness and 1 " in diameter that were doped with non-radioactive salts of cesium and zirconium. SIMCON I coupons simply have the salts dried on the surface, while SIMCON II coupons have the salts dried onto the surface and then baked in an oven at $700 \mathrm{deg} C$ for 24 hours. SIMCON I is comparable to loose surface contamination and SIMCON $\Pi$ is comparable to fixed contamination. An X-Ray Florescence (XRF) analysis is used to determine the amount of zirconium and cesium on the SIMCON coupons both before and after cleaning. "Percent removal" factors are then determined by comparing the data.

\subsection{LABORATORY TESTS}

Strippable coatings are most often used to protect areas that may become contaminated in the future. They are generally not very good for decontaminating, as they tend not to remove fixed contamination, and usually have only limited effectiveness on loose contamination. The results of these strippable coatings using SIMCON I and SMCON II coupons are shown in Table 1. 
Table 1. Comparison of stripcoat testing with SIMCON coupons.

\begin{tabular}{ccccc}
\hline Stripcoat Material & $\begin{array}{c}\text { SIMCON I Cs } \\
\text { (\% Removal) }\end{array}$ & $\begin{array}{c}\text { SIMCON I Zr } \\
\text { (\% Removal) }\end{array}$ & $\begin{array}{c}\text { SIMCON II Cs } \\
\text { (\% Removal) }\end{array}$ & $\begin{array}{c}\text { SIMCON II Zr } \\
\text { (\% Removal) }\end{array}$ \\
\hline TLC Stripcoat & 87 & 66 & 42 & 73 \\
ALARA 1146 & 83 & 76 & 45 & 76 \\
PENTEK 604 & 96 & 90 & 57 & 75 \\
\hline
\end{tabular}

TLC Stripcoat and ALARA 1146 are relatively easy to use. TLC Stripcoat may be brushed, sprayed, or even poured on a surface and peels very easily. ALARA 1146 is difficult to remove if not sprayed onto the surface to achieve a coating thickness of about 1 mil. If applied by brush or other method, it tends to be very difficult to peel. Some operating experience at INEEL using ALARA 1146 has shown that this type of coating is difficult to use in the reprocessing environment, and returned little benefit, removing only loosely held contamination.

PENTEK 604 self-stripping coating is better at decontaminating SIMCON I coupons than the other strippable coatings. PENTEK 604 was brushed on the surface of SIMCON I coupons and left to dry approximately 12 hours in a room that was at a temperature of approximately $60^{\circ} \mathrm{F}$. During this 12 -hour period the coupons were checked after 5 hours and $90 \%$ of the coating had released from the surface. The remainder of the coupons were left overnight to finish drying. The coupons were checked the following day and all the coating had released from the coupons. When the coating released from the surface it came off in large pieces. The results from this test prompted more testing with PENTEK 604.

The PENTEK 604 coating was not as effective at cleaning SIMCON II coupons or fixed contamination as it was on loose. During the SIMCON II cleaning portion of the PENTEK 604 test, the first six coupons were coated with strippable coating and left to dry for approximately 12 hours. The coupons were checked after 5 hours and none of the coating had released from the surface. The coupons were then checked the following day and a small portion of the strippable coating had released from the surface but the majority of the coating remained attached to the surface. The coating was removed with a scraper. The second application was applied after the first application had dried and been removed (by scraping). After letting the second application dry, the coating still did not release from the surface and had to be removed (by scraping). A third set of coupons was used to see if the first dry coat could be removed from the coupon by applying a second application of strippable coating over the top of the first. The second application did remove some of the first coat but the majority of the strippable coating still remained on the coupon. This also had to be removed with a scraper. The coating, removed with the scraper, didn't come off in large pieces like the SIMCON I coupons. A representative from PENTEK noted this had been a problem before, and mentioned that if the surface is extremely dirty the coating will not release. Temperature and humidity of the area are also important factors when using PENTEK 604. Even with these concerns, the PENTEK 604 removed in the range of $60-75 \%$ of the fixed contamination.

Another problem encountered in testing PENTEK 604 is the application method. The recommended application is with a brush or roller. Other companies have tried to spray this coating, but with no success. A spray application significantly decreases labor time, which is very important in radioactive areas. This method could be used to decontaminate containment tents and stainless steel walls in cells. Currently containment tents are decontaminated using spray-on/wipe-off methods or just taken down and thrown away because of the time it takes to decontaminate the tent. 
The first step of spraying PENTEK 604 was to optimize the pressures and water to coating ratio that would permit the coating to be sprayed out of a spray gun. A one-quart, automotive type, spray gun was used. It was found that a ratio of 1 part coating to 1 part water worked the best. However, small amounts of water were added during the spraying operation when a snow-like substance was noticed coming out of the sprayer. Blasting pressures between 25 and 30 psig produced the best results. Each previously cleaned coupon was sprayed so that the entire surface was covered with a light coating (which means that the coating was not dripping off the surface). After each coupon was sprayed it was left to dry for approximately 1 minute before another coat was applied. Three coats with one minute drying time between each coat were found to achieve $100 \%$ release of the coating from the surface. During this part of the test, a wrench, a stainless steel block, shoe covers and fiberglass grating were sprayed to see if the coating would release from the surface of these items. The coating did release from all these items. A small containment tent was sprayed to see if the coating would release from the surface of the tent. The coating, which was applied in 3 coats. with the sprayer, released completely from the surface of the tent. Results from the spraying of previously cleaned coupons can be seen in Table 2.

Table 2. PENTEK 604 spraying pressure tests.

\begin{tabular}{cccccc}
\hline $\begin{array}{c}\text { Spraying } \\
\text { Pressure }\end{array}$ & $\begin{array}{c}\text { Number of } \\
\text { Coats }\end{array}$ & $\begin{array}{c}\% \\
\text { Released }\end{array}$ & $\begin{array}{c}\text { Spraying } \\
\text { Pressure }\end{array}$ & $\begin{array}{c}\text { Number of } \\
\text { Coats }\end{array}$ & $\begin{array}{c}\% \\
\text { Released }\end{array}$ \\
\hline $20 \mathrm{psi} \#$ & 1 & 5 & $30 \mathrm{psi}$ & 1 & 5 \\
$20 \mathrm{psi} \#$ & 2 & $100^{*}$ & $30 \mathrm{psi}$ & 2 & 100 \\
$20 \mathrm{psi} \#$ & 3 & $100^{*}$ & $30 \mathrm{psi}$ & 3 & $100^{*}$ \\
$25 \mathrm{psi}$ & 1 & 10 & $35 \mathrm{psi}$ & 1 & 5 \\
$25 \mathrm{psi}$ & 2 & 100 & $35 \mathrm{psi}$ & 2 & 20 \\
$25 \mathrm{psi}$ & 3 & $100^{*}$ & $35 \mathrm{psi}$ & 3 & 100 \\
\hline
\end{tabular}

* Took longer than 2 hours to dry and release from surface.

\# When blasting at this pressure the strippable coating began to form strings after being sprayed out of the gun.

The new spray technique was applied to SIMCON I coupons to see how effective the sprayed coating was at removing contamination. These results are collected in Table 3 . Slightly better results were achieved by spraying the coating versus brushing. Both methods removed $90-99 \%$ of the loose contamination on the coupons with one application. The best overall results were achieved at about $30 \mathrm{psi}$.

Table 3. PENTEK 604 SIMCON I decontamination spray test.

Blasting Pressure Number of Coats $\quad$ Average \% Removed

\begin{tabular}{lll}
\hline $45 \mathrm{psi}$ & 3 & $\mathrm{Cs}-98 \%, \mathrm{Zr}-88 \%$ \\
$45 \mathrm{psi}$ & 4 & $\mathrm{Cs}-99 \%, \mathrm{Zr}-90 \%$ \\
$40 \mathrm{psi}$ & 3 & $\mathrm{Cs}-98 \%, \mathrm{Zr}-89 \%$ \\
$35 \mathrm{psi}$ & 3 & $\mathrm{Cs}-99 \%, \mathrm{Zr}-93 \%$ \\
$30 \mathrm{psi}$ & 3 & $\mathrm{Cs}-99 \%, \mathrm{Zr}-93 \%$ \\
$30 \mathrm{psi}$ & 2 & $\mathrm{Cs}-97 \%, \mathrm{Zr}-95 \%$ \\
$25 \mathrm{psi}$ & 3 & $\mathrm{Cs}-98 \%, \mathrm{Zr}-90 \%$ \\
$20 \mathrm{psi}$ & 3 & $\mathrm{Cs}-99 \%, \mathrm{Zr}-94 \%$ \\
\hline
\end{tabular}

The test proved that PENTEK 604 could be sprayed instead of being rolled or brushed onto the surface. In fact, this method of delivering the coating is just as effective at removing contamination from SIMCON coupons as when it was rolled or brushed onto the surface. 
Another test was performed to determine if PENTEK 604 would remove oil and grease from stainless steel and aluminum. The test consisted of smearing grease and oil on stainless steel and aluminum and then coating these surfaces with PENTEK 604. However, the coating must be rolled or brushed onto the surface. When spraying the coating onto the oil and grease it would not stick because the PENTEK 604 has to be diluted with water in order for it to be sprayed. This dilution when sprayed onto the oil and grease caused the coating to bead and run off the surface. The coating was able to remove the oil and grease from the substrate when it was rolled or brushed onto the stainless steel and aluminum.

\subsection{FIELD TESTING}

After the laboratory tests were completed, several hot tests were performed using PENTEK 604 and TLC on the INEEL contaminated materials. The hot tests included tests on a lead brick, lightly contaminated materials from the fuel storage basin, and heavily contaminated materials from fuel processing.

The first hot test conducted was to test the effectiveness of PENTEK 604 on lead brick cleaning. The test of the lead brick was not performed to clean it to releasable levels, but to remove enough of the contamination so the brick could be used in further decontamination testing at another site (with lower contamination restrictions). The initial contamination on the lead brick was reduced by a factor of ten. These results are shown in Table 4. During the decontamination of the lead brick at INEEL, the strippable coating was applied three separate times. Each application of strippable coating was left to dry for one day. The first two coats were applied to the brick with a small brush. The third and final coat was applied by pouring the strippable coating onto the surface of the brick. The third coat of strippable coating took about 12 hours longer to dry because it was not a uniform coating like the previous two coats. All three coats of PENTEK 604 released from the surface of the brick. The strippable coating only stuck to areas where there were deep pores or cracks in the brick. The strippable coating in these areas was easily scraped off the surface with a small hand scraper.

Table 4. Results of contaminated lead brick cleaning.

\begin{tabular}{ccccc}
\hline Applications & $\begin{array}{c}\text { Before } \\
\text { Fixed } \\
\text { Beta-gamma } \\
(\mathbf{c} / \mathbf{m})\end{array}$ & $\begin{array}{c}\text { After } \\
\text { Fixed } \\
\text { Beta-gamma } \\
(\mathbf{c} / \mathbf{m})\end{array}$ & $\begin{array}{c}\text { Before } \\
\text { Smearable } \\
\text { Beta-gamma/ } \\
\text { Alpha (c/m) }\end{array}$ & $\begin{array}{c}\text { After Smearable } \\
\text { Beta-gamma/ } \\
\text { Alpha (c/m) }\end{array}$ \\
\hline First & $*$ & $*$ & $4715 / 26$ & $376 / 0$ \\
\hline Second & $*$ & 15,000 & $376 / 0$ & $150 / 0$ \\
\hline Third & 15,000 & 6000 & $150 / 0$ & $* *$ \\
\hline$*=$ unknown, $* *=$ well below free release criteria $(<200$ dpm Beta-gamma, $<10$ dpm Alpha)
\end{tabular}

The total amount of waste that was generated from the three coats of strippable coating was approximately $80 \mathrm{ml}$ of solid waste was collected as the coating fell off the surface. During the testing of the strippable coating, the radiation technician that covered the job was impressed with the results of the strippable coating and how the coating controlled the spread of contamination.

Several "criticality barriers" were decontaminated as part of these hot tests. These stainless steel "plates" were used in the fuel pools to separate spent fuel during storage and were contaminated with low levels of cobalt- 60 and cesium-137. There was the potential to reuse the barriers if they could be 
decontaminated enough to be sheared in an essentially "cold" process. In the past, the criticality barriers were sprayed with high-pressure water, but this method had not been effective at reducing the contamination levels enough to allow the shearing work. The barriers didn't have to be cleaned to free release criteria but the contamination level had to be low enough they could be removed from the building and transported to another facility for cutting.

Five of the stainless steel barriers were tested using PENTEK 604. The coating was applied to both sides of the barrier using a paintbrush and then left to dry overnight. PENTEK 604 was able to remove the smearable contamination from the lids. However, a small amount of fixed contamination remained, preventing free release. The results from this test can be seen in Table 5 .

Table 5. PENTEK 604 cleaning results for criticality barriers.

\begin{tabular}{|c|c|c|c|c|}
\hline Item & $\begin{array}{c}\text { Smearable Before } \\
\text { Beta/Gamma } \\
\left(\mathrm{dpm} / 100 \mathrm{~cm}^{2}\right)\end{array}$ & $\begin{array}{c}\text { Smearable Before } \\
\text { Alpha } \\
\left(\mathrm{dpm} / 100 \mathrm{~cm}^{2}\right) \\
\end{array}$ & $\begin{array}{l}\text { Smearable After } \\
\text { Beta/Gamma } \\
\left(\mathrm{dpm} / 100 \mathrm{~cm}^{2}\right)\end{array}$ & $\begin{array}{c}\text { Smearable After } \\
\text { Alpha } \\
\left(\mathrm{dpm} / 100 \mathrm{~cm}^{2}\right)\end{array}$ \\
\hline Criticality & Front 43944 & Front 348 & Front $<1000$ & Front $<20$ \\
\hline $\begin{array}{l}\text { Barrier Lid } \\
\# 1\end{array}$ & Back 132681 & Back 755 & Back 1331 & Back 22 \\
\hline Criticality & Front 13594 & Front 237 & Front $<1000$ & Front $<20$ \\
\hline $\begin{array}{l}\text { Barrier Lid } \\
\# 2\end{array}$ & Back 20931 & Back 200 & Back $<1000$ & Back $<20$ \\
\hline Criticality & Front 51856 & Front 452 & Front $<1000$ & Front $<20$ \\
\hline $\begin{array}{l}\text { Barrier Lid } \\
\# 3\end{array}$ & Back 12362 & Back 104 & Back $<1000$ & Back $<20$ \\
\hline Criticality & Front 22513 & Front 192 & Front $<1000$ & Front $<20$ \\
\hline $\begin{array}{l}\text { Barrier Lid } \\
\# 4\end{array}$ & Back 10013 & Back 104 & Back $<1000$ & Back $<20$ \\
\hline Criticality & Front 16294 & Front 126 & Front $<1000$ & Front $<20$ \\
\hline $\begin{array}{l}\text { Barrier Lid } \\
\# 5\end{array}$ & Back 67075 & Back 489 & Back $<1000$ & Back $<20$ \\
\hline
\end{tabular}

Another challenge to PENTEK 604 self-stripping coating was "ROVER" ash covered metal. The ROVER fuel reprocessing process was being decommissioned and a metal artifact was secured for testing. ROVER used large fluidized burners to incinerate graphite fuel for subsequent dissolution and recovery of the uranium. The "greasy", partially burned, graphite is very difficult to remove and often requires very harsh chemicals with lots of scrubbing. These tests were conducted to determine if PENTEK 604 could be used to remove the greasy ash contamination. An approximately $1^{\prime} \times 1$ ' Hastalloy-X (a high cobalt steel) plate contaminated with ROVER ash was obtained. The plate was coated with one coat of PENTEK 604 using a small paintbrush and left to dry for about 16 hours. The next moming most of the coating had fallen off the surface and only a small portion had to be scraped off. The contamination levels fell from $20482 \mathrm{dpm}$ beta/gamma to $182 \mathrm{dpm}$ and from $1768 \mathrm{dpm}$ alpha to $11 \mathrm{dpm}$ with the one application. Though the use of PENTEK 604 was never widespread in the ROVER decommissioning project (nearly all the material was simply removed and disposed of as is), limited use of this product was adopted.

\subsection{CONCLUSIONS}

Most of the strippable coatings tested were effective at removing loose contamination from metal. Some were even effective at removing fixed contamination. PENTEK 604 and Bartlett TLC are seen as 
superior products with several different uses. However, each application must be examined on a case by case basis to determine the "best coating" by looking at the type of material being cleaned, location, and condition of material being cleaned.

\subsection{REFERENCES}

Demmer, R. L. January 1994, Development of Simulated Contaminants (SIMCON) and Miscellaneous Decontamination Scoping Tests, WINCO external report \#118. 